\title{
MODEL PEMBELAJARAN TEAM ASSISTED INDIVIDUALIZATION DAN KEMAMPUAN PEMECAHAN MASALAH MATEMATIKA SISWA KELAS VIII
}

\author{
Yundiana $^{1}$, Aty Nurdiana ${ }^{2}$, Meilia Hestinova ${ }^{3}$ \\ STKIP PGRI Bandar Lampung ${ }^{1,2,3}$ \\ aty_nurdiana@stkippgribdl.ac.id ${ }^{2}$
}

\begin{abstract}
ABSTRAK
Penelitian ini bertujuan untuk mengetahui apakah ada pengaruh dari model Team Assisted Individualization terhadap kemampuan pemecahan masalah matematika siswa. Penelitian ini menggunakan metode eksperimen dengan populasi seluruh siswa kelas VIII SMP Negeri 26 Bandar Lampung yang terdiri dari 8 kelas dengan jumlah 224 siswa, sedangkan sampel terdiri atas dua kelas yaitu kelas VIII C sebagai kelas ekperimen yang berjumlah 29 siswa dan kelas VIII A sebagai kelas kontrol yang berjumlah 27 siswa. Sampel dipilih dengan menggunakan pengundian. Kemampuan pemecahan masalah matematika siswa dites dengan soal essay sebanyak 5 soal yang terlebih dahulu diuji validitas dan reliabilitasnya. Pengujian hipotesis pada penelitian ini menggunakan uji t. Berdasarkan hasil penelitian dan analisis data bahwa ada pengaruh model pembelajaran Team Assisted Individualization terhadap kemampuan pemecahan masalah matematika siswa kelas VIII semester genap SMP Negeri 26 Bandar Lampung tahun pelajaran 2018/2019.
\end{abstract}

Kata kunci : Team Assisted Individualization, pemecahan masalah

\begin{abstract}
This study aimed to determine whether there was an influence of the Team Assisted Individualization model on the students' mathematical problem solving abilities. This study used an experimental method with a population were all eighth grade students of SMP Negeri 26 Bandar Lampung, consisting of 8 classes with 224 students, while the sample consisted of two classes, class VIII $\mathrm{C}$ as an experimental class totaling 29 students and class VIII A as a control class which numbered 27 students. The samples were selected by using the draw. The students' mathematical problem-solving abilities were tested with 5 question essays, which were first tested for their validity and reliability. The testing the hypothesis of this study using the $t$ test. Based on the results of research and data analysis found the influence of the Team Assisted Individualization learning model on the ability to solve mathematical problem solving for VIII grade students of SMP Negeri 26 Bandar Lampung in the academic year 2018/2019.
\end{abstract}

Keywords : team assisted individualization, problem solving 


\section{PENDAHULUAN}

Matematika merupakan mata pelajaran terpenting di sekolah. Hal ini dapat dilihat bahwa matematika diberikan dan diajarkan dari jenjang pendidikan dasar sampai menengah atas. Selain itu, matematika juga sangat diperlukan dalam kehidupan sehari-hari, karena matematika dapat membantu bidang studi lainnya seperti bidang farmasi, akuntansi, kimia, fisika, geografi, perpajakan dan dapat digunakan untuk berhitung, berdagang dan mengolah data. Sehingga pembelajaran matematika memerlukan alokasi waktu yang lebih lama dibandingkan dengan mata pelajaran lainnya.

Tujuan pembelajaran matematika salah satunya ialah siswa mampu memecahkan masalah yang meliputi kemampuan memahami masalah, merancang model matematika, menyelesaikan model, dan menarik kesimpulan. Untuk itu sudah jelas bahwa kemampuan pemecahan masalah merupakan salah satu kemampuan yang harus dimiliki siswa.

Kenyataan yang terjadi di lapangan mengenai kemampuan pemecahan masalah matematika masih jauh dari apa yang diharapkan. Pembelajaran matematika yang ada belum sepenuhnya memberikan kesempatan kepada siswa untuk berpikir logis, kritis, dan luwes dalam sebuah pemecahan masalah. Pembelajaran matematika yang ada belum mampu memunculkan kegunaan matematika dalam kehidupan sehari-hari siswa. Akibatnya siswa hanya memahami konsep secara teoritis saja tanpa terlatih kemampuannya untuk menyelesaikan suatu masalah. Sangat jauh jika siswa diharapkan memiliki sikap menghargai kegunaan matematika dalam kehidupannya. Dengan adanya pembelajaran seperti kenyataan di atas, maka terlihat belum optimalnya kemampuan pemecahan masalah matematika siswa.

Termasuk juga pembelajaran matematika yang diberikan di kelas VIII SMP Negeri 26 Bandar Lampung, masih bersifat satu arah. Siswa terbiasa menerima apa yang telah disiapkan mengenai suatu konsep matematika yang berakibat pada penguasaan konsep tanpa pemahaman mendalam dari konsep tersebut. Siswa juga menjadi lebih tertarik pada hal yang kurang berhubungan dengan materi yang sedang dibahas dan lebih tertarik untuk mengobrol atau berdiskusi mengenai hal lain dibandingkan untuk mendiskusikan masalah matematika yang diterimanya. Terbatas pada siswa yang pandai saja yang merasa bertanggungjawab untuk belajar dan siswa yang kurang pandai terbiasa menyalin dari siswa yang lebih pandai. Sangat terlihat sebagian besar siswa kurang menyukai mata pelajaran matematika.

Selain itu, masih banyak siswa yang mengeluh jika diberikan tugas berupa masalah matematika, mereka lebih memilih untuk mengerjakan soal-soal yang dapat diselesaikan dengan menggunakan rumus tanpa melewati strategi tertentu dalam menemukan solusinya. Pembelajaran matematika juga dianggap sebagai pelajaran yang sulit dan membosankan bagi siswa kelas VIII. Akibatnya, perolehan hasil siswa pada pembelajaran matematika juga belum sesuai harapan sekolah.

Hendriana, dkk (2017:33) menyatakan bahwa masalah dalam matematika adalah persoalan yang tidak rutin, artinya cara metode solusinya belum diketahui. Kegiatan melihat, memeriksa, mencoba, menduga, menemukan dan meninjau kembali merupakan cara untuk mengetahui pemecahan masalah. Dalam pemecahan masalah, siswa dituntut memiliki kemampuan menciptakan gagasan atau cara baru berkenaan dengan permasalahan yang dihadapinya. Oleh karena itu, siswa dituntut untuk memiliki kemampuan menciptakan cara-cara baru berkenaan dengan permasalahan tersebut. Sedangkan Branca (Hendriana, dkk, 2017:33) mengartikan 
bahwa pemecahan masalah merupakan tujuan umum dalam pembelajaran matematika, bahkan sebagai jantungnya matematika artinya kemampuan pemecahan masalah merupakan dasar dalam belajar matematika.

Djamarah (Karim dan Anshariyah, 2016:60) menjelaskan bahwa pemecahan masalah ialah suatu metode berpikir, dimana dalam pemecahan masalah diterapkan metode yang dimulai dari pencarian data sampai kesimpulan. Ditambahkan menurut Lenchner (Karim dan Anshariyah, 2016:60) memecahkan masalah matematika yaitu proses penggunaan pengetahuan tentang matematika yang sudah diperoleh sebelumnya ke dalam situasi baru yang belum diketahui. Sedangkan Dewanti (Karim dan Anshariyah, 2016:60) mengungkapkan bahwa kemampuan pemecahan masalah ialah kemampuan berpikir siswa untuk menyelesaikan suatu persoalan dengan menggunakan strategi, prosedur dan karakteristik sehingga dapat menemukan solusi. Selanjutnya Kesumawati (Karim dan Anshariyah, 2016:60) mengemukakan kemampuan pemecahan masalah matematika merupakan kemampuan mengenali unsur-usur yang diketahui, ditanyakan, dan kecukupan unsur yang diperlukan, mampu membuat atau menyusun model matematika, bisa menentukan dan menguraikan prosedur pemecahan, mampu menelaah dan mengecek kebenaran jawaban yang didapat.

Salah satu upaya untuk memperbaiki kemampuan pemecahan masalah matematika siswa yaitu dengan model pembelajaran Team Assisted Individualization (TAI). Model ini merupakan suatu bentuk model yang menggabungkan pembelajaran kelompok dengan pembelajaran individu. Model ini dirancang untuk mengatasi kesulitan belajar siswa secara individual dalam kelompok serta meningkatkan aktivitas belajar siswa dalam kelas.

Ciri pembelajaran Team Assisted Individualization (TAI) adalah setiap siswa belajar materi yang sudah disiapkan oleh guru secara individu. Kemudian hasil belajar tersebut didiskusikan dan dibahas di kelompok dan semua anggota kelompok bertanggungjawab bersama. Dengan adanya pemahaman siswa yang lebih dalam diskusi, model Team Assisted Individualization (TAI) ini mampu memudahkan siswa dalam aktivitas pemecahan masalah matematika.

Menurut Slavin (2011:187) dasar dari model pembelajaran Team Assisted Individualization (TAI) ialah untuk mengadaptasi pengajaran terhadap perbedaan individual yang berkaitan dengan kemampuan siswa maupun pencapaian prestasi siswa. Selanjutnya Slavin (2011:189) berpendapat pandangan dari Team Assisted Individualization (TAI) didasari sebagai usaha untuk merancang sebuah bentuk pengajaran individu dengan membuat siswa bekerja dalam kelompok pembelajaran kooperatif dan mengemban tanggungjawab mengamati dan menjalankan secara rutin, sama-sama menyokong satu sama lain dalam menghadapi masalah, dan saling memberi dorongan untuk maju, maka dapat mengurangi keterlibatan guru dalam memberikan pemeriksaan dan pengajaran langsung dengan siswa bekerja dalam kelompok.

Pembelajaran kooperatif tipe Team Assisted Individualization (TAI) mengkolaborasi keutamaan pembelajaran kooperatif (belajar secara kelompok) dengan pembelajaran individual dengan tujuan untuk mengatasi kesulitan belajar siswa secara individual. Ciri dari Team Assisted Indivualization (TAI) yaitu setiap siswa belajar secara individu dengan materi yang sudah disiapkan oleh guru. Siswa dibentuk kelompok, tetapi setiap siswa belajar sesuai dengan kemampuan dan kecepatan masing-masing. Kemudian hasil belajar setiap individu dikumpulkan ke 
kelompok untuk dibahas dan didiskusikan oleh anggota kelompok dan semua bertanggungjawab atas semua jawaban sebagai tanggung jawab seluruh anggota kelompok. Setiap anggota kelompok saling membantu dan saling mengecek sehingga siswa merasa benar-benar ikut ambil bagian dan berperan aktif dalam proses pembelajaran (Ramlan, 2013:113).

Alsa (2011:83) berpendapat bahwa pada Team Assisted Individualization (TAI) siswa dibentuk ke dalam beberapa kelompok yang terdiri dari 4 atau 5 siswa dengan bersifat heterogen. Guru hanya memberikan materi secara singkat kemudian memberikan tugas pada masing-masing anggota kelompok harus saling bekerja sama dalam menyelesaikan tugas tersebut. Para siswa selanjutnya dites secara individu. Siswa yang berhasil memperoleh skor tertinggi akan diberikan penghargaan.

Lestari dan Yudhanegara (2015:49) mengemukakan bahwa model pembelajaran Team Assisted Individualization (TAI) merupakan salah satu tipe model pembelajaran yang mengkombinasikan keunggulan pembelajaran kooperatif dan pembelajaran individual. Sedangkan Shoimin (2014:200) menambahkan bahwa model pembelajaran Team Assisted Individualization (TAI) mempunyai dasar pemikiran yaitu untuk mengadaptasi pembelajaran terhadap perbedaan individual yang berkaitan dengan kemampuan maupun pencapaian prestasi siswa.

Berdasarkan latar belakang masalah siswa kelas VIII SMP Negeri 26 Bandar Lampung mengenai masih lemahnya kemampuan pemecahan masalah matematis siswanya, maka perlu dilakukan penelitian yang bertujuan untuk mengetahui pengaruh dari model Team Assisted Individualization terhadap kemampuan pemecahan masalah matematika siswa kelas VIII SMP Negeri 26 Bandar Lampung.

\section{METODE}

Penelitian ini menggunakan metode eksperimen yang dilaksanakan di SMP Negeri 26 Bandar Lampung dengan populasi yang berjumlah 224 siswa yang tersebar dalam 8 kelas. Dari jumlah populasi tersebut diambil 2 kelas yang dianggap dapat menjadi sampel penelitian. Dengan menggunakan tehnik cluster random sampling, terpilih kelas VIII C dengan jumlah 29 siswa sebagai kelas eksperimen dan kelas VIII A dengan jumlah 27 siswa sebagai kelas kontrol. Penelitian dilaksanakan dari pukul 08.00 sampai 09.30 WIB, pada hari Selasa dan Kamis dimulai dari bulan Februari sampai pertengahan April pada tahun 2019.

Untuk menghitung kemampuan pemecahan masalah matematika siswa, diperlukan indikator guna menjadi acuan dalam pemberian nilai. Tolok ukur penilaian menurut Polya (1985: 6) ada beberapa tahapan dalam kemampuan pemecahan masalah matematika, yaitu: (1) Memahami masalah. Siswa dapat melakukannya dengan mengulang pertanyaan, membuat poin yang merupakan permasalahannya, menunjukkan hal-hal yang ditanyakan serta hal-hal yang diketahui dari permasalahan yang diberikan; (2) Merencanakan. Perencanaan dibuat ketika kita mengetahui atau setidaknya secara garis besar memahami perhitungan, langkah untuk menyelesaikan hal-hal yang kita pahami pada langkah pertama; (3) Melaksanakan rencana. Untuk melaksanakan rencana dalam memperoleh ide untuk menentukan solusi, diperlukan pengetahuan yang memadai, konsentrasi terhadap tujuan, semangat dan harus mempunyai kesabaran; (4) Lihatlah kembali. Jika siswa telah menemukan solusi dari permasalahannya dan menuliskan argumen serta alasannya secara lengkap dalam bukunya serta memahami cara lainnya itu artinya 
mereka telah mencapai solusi yang sempurna dan telah melakukan pengecekan terhadap langkahnya.

Data penelitian dikumpulkan dengan menggunakan tes. Tes yang dipakai adalah tes tertulis yang berbentuk soal uraian (essay) dengan jumlah 5 soal. Tes tertulis ini berfungsi untuk mengetahui kemampuan pemecahan masalah matematika siswa setelah mengikuti pembelajaran. Tehnik analisis data hasil penelitian menggunakan analisis statistik, karena data yang dikumpulkan adalah data kuantitatif atau berupa angka yang didapat dari hasil tes dan diberi nilai. Dilakukan uji prasyarat (uji normalitas dan uji homogenitas) terlebih dahulu, lalu dilakukan uji t.

\section{HASIL DAN PEMBAHASAN}

Dari hasil postes pada kedua kelas diperoleh adanya perbedaan hasil mengenai kemampuan pemecahan masalah matematika siswa baik pada kelas eksperimen maupun pada kelas kontrol.

Data-data yang diperoleh setelah melalui proses perhitungan untuk masingmasing nilai siswa diperoleh nilai-nilai yang berbeda. Adapun gambaran perbandingan hasil perhitungan tentang pemecahan masalah matematika siswa pada kelas eksperimen dan kontrol adalah sebagai berikut:

Tabel 1. Kemampuan pemecahan masalah matematika siswa

\begin{tabular}{lcc}
\hline \multicolumn{1}{c}{ Keterangan } & Kelas eksperimen & Kelas kontrol \\
\hline Jumlah siswa & 29 & 27 \\
Nilai tertinggi & 100 & 82 \\
Nilai terendah & 60 & 40 \\
Rata-rata & 80,17 & 62,07 \\
Median & 80 & 60 \\
Modus & 70 & 60 \\
Simpangan baku & 11,63 & 12,17 \\
\hline
\end{tabular}

Berdasarkan tabel di atas, terlihat bahwa adanya perbedaan antara kemampuan pemecahan masalah matematika siswa yang diajar menggunakan model pembelajaran Team Assisted Individualization (TAI) dengan mereka yang diajar menggunakan model konvensional. Di kelas eksperimen nampak bahwa nilai siswa yang menggunakan model Team Assisted Individualization (TAI) lebih besar dibandingkan kelas kontrol yang menggunakan model kovensional.

Langkah-langkah pembelajaran Team Assisted Individualization (TAI) dilakukan dengan 8 tahapan yang mengacu pada pendapat Shoimin (2014:200), yaitu: (1) Placement Test, pada langkah ini guru memberikan pretes kepada siswa; (2) Teams, guru membentuk kelompok-kelompok yang bervariasi yang terdiri dari 4 sampai 5 siswa; (3) Teaching Grup, guru memberikan materi secara singkat sebelum pemberian tugas kelompok; (4) Student Creative, guru menekankan dan menciptakan persepsi bahwa keberhasilan setiap siswa (individu) ditentukan oleh keberhasilan kelompoknya; (5) Team Study, siswa belajar bersama mengerjakan tugas yang diberikan dalam kelompoknya yang dibantu oleh siswa yang memiliki kemampuan akademis bagus di dalam kelompok tersebut yang berperan sebagai tutor sebaya, disini tugas guru hanya mengarahkan bantuan secara individual kepada siswa yang membutuhkan; (6) Fact Test, guru memberikan tes-tes kecil berdasarkan fakta 
yang diperoleh siswa, misalnya dengan memberikan kuis; (7) Team Score and Team Recognition, guru memberikan skor pada hasil kerja kelompok dan memberikan penghargaan "gelar" terhadap kelompok yang berhasil dalam menyelesaikan tugas; (8) Whole-Class Unit, guru menjelaskan kembali materi di akhir setelah selesai proses pembelajaran.

Siswa dibentuk dalam kelompok belajar heterogen dimana pembelajaran dimulai dengan pretes untuk menentukan siswa yang lebih pandai dibanding lainnya yang nantinya akan berperan sebagai tutor sebaya yang bertugas membantu secara individual siswa lain yang kurang mampu dalam suatu kelompok untuk menyelesaikan masalah yang diberikan dalam menciptakan skor kelompok Team Assisted Individualization (TAI).

Selain itu dengan menerapkan model pembelajaran Team Assisted Individualization (TAI) sikap keterampilan dan sosial siswa semakin baik. Hal ini terlihat saat mereka melakukan diskusi dengan kelompoknya, mereka saling membantu untuk dapat mengerjakan tugas yang diberikan oleh guru sebagai bentuk tanggungjawab bersama. Begitu juga dengan sikap keterampilannya, yang menggunakan model pembelajaran Team Assisted Individualization (TAI) siswa semakin kreatif dalam memecahkan, merencanakan dan menyelesaikan suatu permasalahan matematika. Dengan demikian siswa semakin termotivasi lebih kreatif karena adanya sebuah penghargaan untuk kelompok yang unggul.

Demikianlah keadaan pembelajaran pada kelas VIII C sebagai kelas eksperimen yang menggunakan model pembelajaran Team Assisted Individualization (TAI) memperlihatkan situasi siswa yang aktif bersama kelompoknya untuk menganalisis, merencanakan, dan menyelesaikan suatu permasalahan matematika. Dalam kelas eksperimen juga setiap anggota terlihat bertanggungjawab untuk mengisi lembar kerja yang diberikan dan berusaha menyelesaikan permasalahan dengan baik. Setiap kelompok terlihat berlomba untuk mendapatkan skor terbaik dan tentunya untuk mendapatkan penghargaan kelompok. Dengan demikian jelas bahwa reward ini dapat dijadikan sebagai motivasi eksternal bagi kelompok siswa. Dengan demikian jelas bahwa suasana pembelajaran kelas eksperimen berpusat pada siswa.

Keadaan siswa pada kelas kontrol justru menunjukkan keadaan yang berlawanan. Pada kelas kontrol siswa terlihat pasif dan cukup susah menerima materi yang diberikan oleh guru. Sepanjang pembelajaran guru terus berceramah untuk menyampaikan materi. Siswa tidak terlalu dilibatkan untuk bekerja dalam memecahkan masalah. Guru sangat mendominasi kelas. Akibatnya siswa bosan dan nampak malas dalam belajar.

Hasil penelitian pada kelas eksperimen, diperoleh rata-rata nilai tes kemampuan pemecahan masalah matematika siswa lebih tinggi yaitu 80,17, sedangkan siswa pada kelas kontrol nilainya lebih rendah dengan rata-rata yaitu 62,07 .

Kemudian dilakukan uji normalitas dan uji homogenitas. Uji ini digunakan untuk melihat apakah data yang diuji berasal dari populasi yang berdistribusi normal dan mempunyai varians yang sama. 
Tabel 2. Uji normalitas kelas eksperimen dan kelas kontrol

\begin{tabular}{lccc}
\hline \multicolumn{1}{c}{ Kelas } & $L_{0}$ & $L_{\text {tabel }}$ & Keterangan \\
\hline Eksperimen & 0,1181 & 0,1634 & Normal \\
Kontrol & 0,1225 & 0,1682 & Normal \\
\hline
\end{tabular}

Berdasarkan hasil uji normalitas data, dengan menggunakan Uji Liliefors pada taraf nyata $(\alpha)=5 \%$ didapatkan $L_{\text {tabel }}=0,134$. Kemudian, untuk kelas eksperimen diperoleh $L_{0}=0,1181$ dan kelas kontrol $L_{0}=0,1225$. Dengan kriteria uji, tolak Ho jika $L_{0}>L_{\text {tabel }}$. Ternyata dari data diperoleh $L_{0}$ kedua kelas kurang dari $L_{\text {tabel }}$, maka data kedua kelas berasal dari populasi yang berdistribusi normal.

Tabel 3. Uji homogenitas varians kelas eksperimen dan kelas kontrol

\begin{tabular}{|c|c|c|c|c|}
\hline Kelas & $\mathrm{N}$ & $F_{\text {hitung }}$ & $F_{\text {tabel }}$ & Keterangan \\
\hline Eksperimen & 29 & \multirow{2}{*}{1,09} & \multirow{2}{*}{1,92} & \multirow{2}{*}{ Homogen } \\
\hline Kontrol & 27 & & & \\
\hline
\end{tabular}

Berdasarkan tabel 3, pada taraf nyata $(\alpha)=5 \%$ diperoleh $F_{\text {tabel }}=1,92$ dan $F_{\text {hitung }}=1,09$. Berdasarkan kriteria uji, tolak Ho jika $F_{\text {hitung }}>F_{\text {tabel }}$. Dengan demikian, dapat dilihat bahwa Ho diterima atau dapat disimpulkan kedua data mempunyai varians yang sama.

Setelah dilakukan uji normalitas dan uji homogenitas, didapatkan kedua data berdistribusi normal dan homogen, maka uji hipotesis kesamaan dua rata-rata yang digunakan adalah uji t.

Tabel 4. Uji hipotesis kesamaan dua rata-rata

\begin{tabular}{lccccccc}
\hline \multicolumn{1}{c}{ Kelas } & $\mathrm{N}$ & $\bar{x}$ & $s^{2}$ & $S^{2}$ & $t_{\text {hitung }}$ & $t_{\text {tabel }}$ & Keterangan \\
\hline Eksperimen & 29 & 80,17 & 135,36 & \multirow{2}{*}{11,90} & 5,63 & 2,00 & \multirow{2}{*}{ Tidak sama } \\
\hline Kontrol & 27 & 62,07 & 148,07 & & & & \\
\hline
\end{tabular}

Berdasarkan hasil perhitungan lengkap yang menggunakan uji-t pada taraf nyata $(\alpha)=5 \%$ diperoleh $t_{\text {tabel }}=2,00$ dan $t_{\text {hitung }}=5,63$, dengan kriteria uji terima Ho jika $-t_{(1-1 / 2 \alpha)}<t_{\text {hitung }}<t_{(1-1 / 2 \alpha)}$. Karena $t_{\text {hitung }}>t_{\text {tabel }}$, maka Ho ditolak dan $\mathrm{Ha}$ diterima. Artinya rata-rata kemampuan pemecahan masalah matematika siswa yang diterapkan model Team Assisted Individualization (TAI) tidak sama dengan rata-rata kemampuan pemecahan masalah matematika siswa yang diterapkan pembelajaran konvensional pada siswa kelas VIII SMPN 26 Bandar Lampung tahun pelajaran 2018/2019 atau dapat dikatakan ada pengaruh perlakuan yang diberikan.

Beberapa penelitian lain yang mendukung hasil penelitian ini, yaitu penelitian Farnika, Ikhsan, dan Sofyan (2015) yang menyimpulkan bahwa: 1) peningkatan kemampuan pemecahan masalah matematis siswa yang memperoleh pembelajaran dengan menggunakan model kooperatif tipe TAI lebih baik daripada siswa yang memperoleh pembelajaran konvensional ditinjau berdasarkan keseluruhan siswa, dan level siswa (tinggi, sedang dan rendah), dan 2) terdapat interaksi antara model 
pembelajaran dan level siswa (tinggi, sedang, dan rendah) terhadap peningkatan kemampuan pemecahan masalah matematis.

Penelitian Dahlan (2016) juga menyimpulkan bahwa terdapat perbedaan pencapaian kemampuan pemecahan masalah matematika siswa antara kelas yang diajar dengan model TAI, kelas yang diajar dengan model Jigsaw, dan kelas yang diajar dengan pembelajaran konvensional. Dapat dilihat juga dari Uji Scheffe bahwa model pembelajaran yang paling efektif digunakan pada kelas VIII MTs X Sumedang pada materi pokok relasi dan fungsi adalah model pembelajaran TAI.

Penelitian Utami dan Sucipto (2017) lebih menegaskan lagi bahwa model pembelajaran Team Assisted Individualization (TAI) efektif terhadap kemampuan pemecahan masalah matematika siswa.

\section{SIMPULAN DAN SARAN}

Berdasarkan hasil analisis data yang telah diuraikan dapat disimpulkan bahwa ada pengaruh menggunakan model pembelajaran Team Assisted Individualization (TAI) terhadap kemampuan pemecahan masalah matematika siswa kelas VIII semester genap SMP Negeri 26 Bandar Lampung tahun pelajaran 2018/2019. Dengan rata-rata kemampuan pemecahan pemecahan masalah matematika siswa yang menggunakan model Team Assisted Individualization (TAI) lebih tinggi dari rata-rata kemampuan pemecahan masalah matematika siswa yang menggunakan pembelajaran konvensional.

Dengan melihat hasil penelitian ini, maka disarankan agar guru lebih memaksimalkan dalam pembuatan LKPD, sehingga pelaksanaan pembelajaran melalui model ini dapat berjalan maksimal dan dapat memaksimalkan kemampuan pemecahan masalah matematika siswa.

\section{DAFTAR PUSTAKA}

Alsa, A. 2011. Pengaruh Metode Belajar Team Assisted Individualization Terhadap Prestasi Belajar Statistika pada Mahasiswa Psikologi. Jurnal Psikologi, Vol. 38 (1) : 82-91.

Dahlan, T. 2016. Pengaruh Model Pembelajaran Kooperatif Tipe Team Assisted Individualization dan Jigsaw Terhadap Kemampuan Pemecahan Masalah Matematik Siswa MTs Pada Pokok Bahasan Relasi dan Fungsi. Symmetry: Pasundan Journal of Research in Mathematics Learning and Education, Vol. $\mathrm{I}(1): 29-38$.

Farnika, N., Ikhsan, M., dan Sofyan, H. 2015. Peningkatan Kemampuan Pemahaman dan Pemecahan Masalah Matematis Siswa Sekolah Menengah Atas dengan Model Pembelajaran Kooperatif Tipe Team Assisted Individualization. Jurnal Elemen, Vol. 1(2) : 144-152.

Hendriana, H., Rohaeti, E.E., dan Sumarmo, U. 2017. Hard Skills dan Soft Skills Matematik Siswa. Bandung: Refika Aditama.

Karim dan Anshariyah, A. 2016. Penerapan Model Pembelajaran Kooperatif Tipe Team Assisted Individualization (TAI) untuk Melatih Kemampuan Pemecahan Masalah Matematis Siswa SMA. Edu-Mat Jurnal Pendidikan Matematika, Vol. 4(1) : 58-67.

Lestari, K.E. dan Yudhanegara, M.R. 2015. Penelitian Pendidikan Matematika. Bandung: Refika Aditama. 
Polya, G. 1985. How To Solve It. Second edition. New Jersey: Princeton University Press.

Ramlan, M. 2013. Meningkatkan Self-Efficacy pada Pembelajaran Matematika Melalui Model Kooperatif Tipe Team Assisted Individualization (TAI) pada Siswa Kelas VII SMP Negeri 27 Makasar. Jurnal Matematika dan Pembelajaran (MaPan), Vol 1 (1) : 110-122.

Shoimin, A. 2014. 68 Model Pembelajaran Inovatif dalam Kurikulum 2013. Yogyakarta: Ar-Ruzz Media.

Slavin, R. E. 2011. Cooperative Learning: Teori, Riset, dan Praktik (Indonesian Version). (Zubaedi dan N. Yusron, Transl.). Bandung: Nusa Media.

Utami, S. dan Sucipto, L. 2017. Efektivitas Model Pembelajaran Team Assisted Individualization (TAI) Terhadap Kemampuan Pemecahan Masalah Matematika Siswa Kelas VIII SMP. Jurnal Paedagoria, Vol. 8(2) : 32-36. 